Washington

THE National Aeronautics and Space Administration (NASA) is bracing itself for a complex series of negotiations with Europe, Congress and the space science community before it finalizes plans to build the $\$ 8,000$ million manned space station called for by President Reagan in his State of the Union message earlier this year.

In Washington last week, a delegation from the European Space Agency (ESA) settled down for what is expected to be a difficult round of talks with NASA about the cost and scope of European participation. NASA, under pressure from Congress and the Office of Management and Budget (OMB) to keep the costs of the station as low as possible, hopes to persuade foreign countries to pay up to 30 per cent of the station's cost.

But the Europeans, who are likely to account for between 15 and 20 per cent of the foreign contribution, are expected to drive a hard bargain.

At a meeting in Naples earlier this month, ESA officials said their member governments wanted to be more than subcontractors; they would be willing to join the project only as full partners able to garner the expertise necessary to launch a station of their own, perhaps a decade or so after the US station is launched in 1992. And to avoid repeating their mistakes with Spacelab, they are insisting on guarantees of equal access to the space station and the right to exploit it commercially.

Foreign participation is not the only difficult question NASA has to resolve, however. Although Congress has agreed to provide NASA with the $\$ 150$ million it wants in 1985 for preliminary design studies, both houses have signalled that they are not yet fully convinced of the need for the elaborate permanently manned facility planned by the space agency. Bills passed by the Senate and the House of Representatives instruct NASA to set aside several million dollars for "complementary" design studies of a less grandiose "'man-tended" facility.

Some congressional champions of the space station objected to the requirement for the complementary studies, arguing that it would send "mixed signals" to the private companies looking at the possibility of investing in manufacturing and research in space. But most members felt it was prudent to keep options open as long as possible, in case budget retrenchment later in the decade shoud leave NASA with a half-completed " "hotel in space".

Meanwhile, NASA is negotiating on a third front, with the US space science community. Although at the outset opposed to the decision, space scientists have wasted no time in joining the planning effort to ensure that the scientific yield from the project is as great as possible. Earlier this month, a newly-established advisory committee on the scientific uses of the space station, under the chairmanship of Dr Peter Banks of Stanford University, recommended that the space station should be ac- companied by a flotilla of compact freeflying modular platforms rather than the one or two large unpressurized platforms envisaged by NASA.

A minority of members of the committee is also anxious to persuade NASA to complement the space station, which is to maintain a $400-\mathrm{km}$ east-west orbit at an inclination of 28.5 degrees, with a large free-flying platform in polar orbit. The polar module has been talked about within NASA but is regarded as a prime candidate for cutting in the event of budget difficulties or escalating costs. The platform, regarded as essential by the Earth-observation sciences, is expected to cost at least $\$ 800$ million.

Peter David

\title{
Commercialization of space
}

\section{Whoever will pay the price?}

\section{Washington}

US BUSINESS corporations are asking for extensive government subsidies and risksharing agreements before agreeing to take up President Reagan's call for the rapid commercialization of space. In Congress last week, leaders of three major aerospace corporations said that, without government help, the costs and risks associated with the exploitation of space are simply too high for it to be worth their while to be involved.

The witnesses, from the Fairchild, Grumman and McDonnell Douglas corporations, are all members of an industry-space commercialization committee which recently submitted a swathe of detailed recommendations to the White House. Although the report has not been published, it is clear that it calls for substantial tax incentives, some form of risksharing agreement and enhanced private sector access to the facilities and technical expertise of the National Aeronautics and Space Administration (NASA).

Mr Richard Kline, director of space station operations for the Grumman Aerospace Corporation, told the House of Representatives' subcommittee on space science and applications that the venture capital market rarely finances ventures costing more than $\mathbf{\$ 7 5}$ million and is too small to support significant investments in space. To help companies reduce their initial investment risk, he said, NASA ought to provide "seed money" for the development of initial projects and reduce the flight of shuttle rides. He also called on NASA to expand its effort in promising areas of basic research such as microgravity and high vacuum environments.

Dr John Townsend, president of the Fairchild Space Company, said a number of complex fiscal and regulatory barriers would have to be removed before the private sector could exploit the full commercial potential of space. The major problem, he said, was that since space is not legally part of the United States, capital ventures based in space do not qualify for the 10 per cent investment tax credit. Congress, he said, should extend to all space ventures the special exemption it granted the commercial satellite industry in 1971 .

The White House is expected to consider the private sector's shopping list in conjunction with a separate report on space commercialization drawn up by NASA itself but not yet published. Dr James Beggs, NASA's administrator, admitted that publication had been delayed because of internal disagreements but dodged questions about its specific recommendations. Meanwhile, he made it clear that all was not entirely well with NASA's first great commercial enterprise, its shuttle launch business.

Mr Beggs has two major worries. On the one hand, he is under pressure to reduce the price NASA charges for shuttle flights so that private companies trying to make a profit out of the United States' newlyprivatized expendable launch vehicles (ELVs) will be better able to compete. On the other, he is afraid the Department of Defense (DoD), which was originally expected to account for a third of all flights in the 12-year life of the shuttle programme, may decide to divert a large proportion of those flights to its own ELV fleet. While officially describing its retention of ELVs as a "backup", DoD, which has yet to fly its first military payload aboard the shuttle, has been hinting that ELVS offer a cheaper and more efficient answer to its needs.

Only if DoD kept its military payloads for the shuttle, Beggs said, would the shuttle operation be able to recover its direct (but not its research, development and building) costs by 1988 or 1989 . That was later than expected, because commercial flights began three years later than planned and the market for the shuttle turned out to be smaller than expected. Nevertheless, he said, NASA would start thinking, towards the end of 1986, about the possibility of selling or giving the shuttle fleet to private companies to manage at a profit.
Peter David 